\title{
PHYSICOCHEMICAL ANALYSIS OF SUNFLOWER HONEY FROM BULGARIA
}

\author{
Bulgaristan Ayçiçek Ballarının Fiziko-Kimyasal Analizi
}

\section{Vanya MANOLOVA ${ }^{1}$, Ivayla PARVINA ${ }^{1}$, Todorka YANKOVSKA-STEFANOVA ${ }^{1}$, Ralitsa BALKANSKA ${ }^{2^{*}}$}

\begin{abstract}
${ }^{1}$ Central Laboratory of Veterinary Control and Ecology, Iskarsko shose Street 5, 1528 Sofia, BULGARIA, ORCID No: 00000001-6962-3562, ORCID No: 0000-0002-9844-3250, ORCID No: 0000-0002-5128-8601, Emails: van_manolova@abv.bg i.parvina@abv.bg, todorka.yankovska@gmail.com

2Department of Special Branches - Bees, Institute of Animal Science, Kostinbrod, Spirka Pochivka 1, 2232 Kostinbrod, BULGARIA, ORCID No 0000-0003-3486-1514, Corresponding author / Yazışma Yazarı E-mail: r.balkanska@gmail.com
\end{abstract}

Geliş Tarihi / Received: 06.07.2021～Kabul Tarihi / Accepted:18.09.2021ＤOI: 10.31467/uluaricilik.960751

\begin{abstract}
Physicochemical properties of 27 sunflower honey samples from Bulgaria were investigated. The botanical origin of the samples was ascertained by pollen analysis. The honey samples displayed relative frequencies of Helianthus annuus L. pollen up to $41 \%$. The ranges for water content (15.60$19.30 \%)$, reducing sugars $(72.51-80.80 \%)$, sucrose $(0.50-3.70 \%)$, diastase $(9.00-20.80$ Gothe units), hydroxymethylfurfural (HMF), (0.69-12.40 mg/kg), total acidity $(17.70-36.00 \mathrm{meq} / \mathrm{kg})$, electrical conductivity $(0.23-0.48 \mathrm{mS} / \mathrm{cm})$, proline $(218.50-679.50 \mathrm{mg} / \mathrm{kg})$, specific rotation $(-20.20-(-12.30))$ $[\alpha]_{D^{20}}$ were obtained. The results obtained also suggest that these honey samples are of good quality. The results are in agreement with standards of quality established by national and international regulations. Significant moderate correlation between electrical conductivity and specific rotation was found $(r=0.582, p<0.05)$.
\end{abstract}

Keywords: Honey, sunflower honey, physicochemical properties, quality parameters

\section{ÖZ}

Bulgaristan'dan alınan 27 ayçiçeği balı örneğinin fiziko-kimyasal özellikleri araştırıldı. Örneklerin botanik kökeni polen analizi ile belirlendi. Bal numuneleri, \%41'e varan oranlarda Helianthus annuus L. polen sıklığı göstermiştir. Su içeriği (\%15.60 - 19.30), indirgeyici şekerler (\%72.51 - 80.80), sakaroz (\%0.50 - 3.70), diastaz ( $9.00-20.80$ Gothe birimleri), hidroksimetilfurfural (HMF), $(0.69-12.40 \mathrm{mg} / \mathrm{kg})$ için aralıklar), toplam asitlik $(17.70-36.00 \mathrm{meq} / \mathrm{kg})$, elektriksel iletkenlik $(0.23-0.48 \mathrm{mS} / \mathrm{cm})$, prolin $(218.50-679.50 \mathrm{mg} / \mathrm{kg})$, spesifik rotasyon $(-20.20-(-12.30))[\alpha]_{\mathrm{D}}{ }^{20}$ elde edildi. Elde edilen sonuçlar da bu bal örneklerinin kaliteli olduğunu göstermektedir. Sonuçlar, ulusal ve uluslararası düzenlemeler tarafından belirlenen kalite standartları ile uyumludur. Elektriksel iletkenlik ile özgül rotasyon arasında orta düzeyde anlamlı korelasyon bulundu $(r=0,582, p<0,05)$.

Anahtar Kelimeler: Bal, ayçiçeği balı, fiziko-kimyasal özellikler, kalite parametreleri 


\section{ARAŞTIRMA MAKALESI / RESEARCH ARTICLE}

\section{GENIŞLETILMIŞ ÖZET}

Giriş: Çiçek balı, bal arıları (Apis mellifera L.) tarafından bitkilerin nektarından üretilen doğal bir maddedir. Bal, tek çiçekli bitki veya çok bitki kaynağı olarak sınıflandırıır. Tek çiçekli bitki balı, ağırlıklı olarak nektar ve polen içeren bir bitki türü tarafından üretilir. Farklı çiçekli bitki balları, tipik melissopalinolojik ve fizikokimyasal özellikler gösterir. Çok kaynaklı bitki balı, hiçbiri baskın olmayan çeşitli bitkilerden nektar ve polenlerden üretilir. Bu çalışma, Bulgaristan'da üretilen ayçiçeği balının fizikokimyasal parametrelerini değerlendirmeyi amaçlamaktadır. Bulgaristan'dan alınan 27 ayçiçeği balı örneğinin fizikokimyasal özellikleri araştırıldı.

Gereç ve Yöntem: Bal örnekleri oda sıcaklığında cam kaplarda muhafaza edilmiştir. Çalışmada 2017 ve 2018 arıcılık sezonlarında hasat edilen arı balının temsili örnekleri kullanılmıştır. Örneklerin botanik kökeni polen analizi ile tespit edilmiştir. Bal numuneleri, \%41'e varan oranlarda Helianthus annuus L. polen sıklığı göstermiştir. Bulgaristan Arı Balı Devlet Standardı 2673-80'e göre H. annuus'tan \%40'a kadar polen içeren bal örnekleri ayçiçeği balı olarak sınıflandırılabilir. Analizler, numunelerin laboratuvara teslim edildiği tarihten itibaren bir ay içinde yapılmıştır. Polen analizi ve fizikokimyasal analizler Bulgaristan, Sofya'daki Veteriner Kontrol ve Ekoloji Merkez Laboratuvarında yapıldı.

Bulgular: Ayçiçeği balının şu parametreleri Avrupa Bal Komisyonu tarafından önerilen yöntemlere göre belirlendi: su içeriği, indirgeyici şekerler, sakaroz, diastaz, HMF, toplam asitlik, elektriksel iletkenlik, prolin ve spesifik rotasyon. Su içeriği (\%15.60 19.30), indirgeyici şekerler (\%72.51 - 80.80), sakaroz (\%0.50 - 3.70), diastaz (9.00 - 20.80 Gothe birimleri), hidroksimetilfurfural (HMF), (0.69 $12.40 \mathrm{mg} / \mathrm{kg}$ ) için aralıklar ), toplam asitlik (17.70 $36.00 \mathrm{meq} / \mathrm{kg})$, elektriksel iletkenlik $(0.23-0.48$ $\mathrm{mS} / \mathrm{cm})$, prolin $(218.50-679.50 \mathrm{mg} / \mathrm{kg})$, spesifik rotasyon $(-20.20-(-12.30))$ elde edildi. Spesifik optik rotasyon, bal örneklerinin çiçek balından geldiğini, dönen negatif olduğunu (laevorotatory) gösterir. Numunelerin çoğu 350 mg/kg'a kadar prolin değerlerine sahiptir. HMF ortalama $2.82 \mathrm{mg} / \mathrm{kg}$ olarak belirlendi. Elde edilen sonuçlar da bu bal örneklerinin kaliteli olduğunu göstermektedir. Sonuçlar, ulusal ve uluslararası düzenlemeler tarafından belirlenen kalite standartları ile uyumludur. Elektriksel iletkenlik ile özgül rotasyon arasında orta düzeyde anlamlı korelasyon bulundu $(r=0,582, p<0,05)$.

Sonuç: Sonuç olarak, tüm bal örnekleri \%40'tan fazla $H$. annuus polen içerir ve ayçiçeği balı olarak sınıflandırılabilir. Ayçiçeği balının su içeriği, indirgeyici şekerler, sakaroz, diastaz, HMF, toplam asitlik, elektriksel iletkenlik, prolin ve özgül rotasyon parametreleri uluslararası yönetmeliklerle belirlenen kalite parametrelerini karşılamaktadır. Bu çalışma, Bulgaristan'dan ayçiçeği balının karakterizasyonu için faydalı bilgiler sağlamaktadır.

\section{INTRODUCTION}

Blossom honey is a natural substance produced by honey bees (Apis mellifera L.) from the nectar of plants. Honey is classified as unifloral or polyfloral. The unifloral honey is produced by one plant species containing predominantly its nectar and pollen. The different unifloral honeys show typical melissopalynological and physicochemical properties. The polyfloral honey is produced from nectar and pollen from various plants, none of which is predominant. In general, unifloral honeys are regarded as more valuable products. They have good quality and specific sensorial characteristics. Furthermore, market prices of honey are determined by its botanical origin. It can be said that monofloral honeys are more expensive than mixed polyfloral honeys. This is due to their pharmacological and organoleptic properties (Silva et al. 2009, Bilandžić et al. 2017). Thus, great attention has been paid for identification of unifloral honey by researchers (Wen et al. 2017). Honey is becoming an effective therapeutic agent by practitioners of conventional medicine due to its chemical composition. In this respect the composition of honey depends on its floral origin (De-Melo et al. 2018, Valdés-Silverio et al. 2018). According to Ahmed et al. (2016) and Saxena et al. (2010) honey includes a lot of substances. The main constituents of honey are carbohydrates and water. Phenolic compounds, amino acids, vitamins, minerals and enzymes are also presented in honey.

In Bulgaria there are low levels of local consumption of bee honey - under $200 \mathrm{~g}$ on average per capita compared to some countries in Western Europe (about $1 \mathrm{~kg}$ on average per year). Bulgarian beekeeping has a traditionally export character. According to Agro-statistics of the Ministry of agriculture and food the export of Bulgarian honey 


\section{ARAŞTIRMA MAKALESI / RESEARCH ARTICLE}

for the period 2015 - 2017 increased from 9784 to 13302 tons per year (Aleksiev 2019). In Bulgaria very often the sunflower honey is mixed with polyfloral honey and it is sold as polyfloral honey.

Different unifloral honey types are produced in Europe. In Bulgaria, one of the most important honey types are black locust honey (Robinia pseudoacacia), lime honey (Tilia spp.), rape honey (Brassica spp.), sunflower honey (H. annuus). Some honey types such as black locust, lime, rape coriander, fennel honey were studied and described by Atanassova et al. (2012), Dinkov (2014) while data for others such as sunflower honey is insufficient. Sunflower is largely cultivated in many European countries because it represents to bees nectar and pollen (Persano Oddo and Piro 2004). To date, several studies have attempted to elucidate the sunflower honey produced in Bulgaria (Nikolova et al. 2014, Atanassova et al. 2012). The present study aims to evaluate physicochemical parameters of sunflower honey produced in Bulgaria. The obtained results were compared with national (Bulgarian State Standard for Bee Honey 3050-80 and Bulgarian State Standard 2673-80) and international regulations (Council Directive 2001/110 relating to honey (2002) and Codex Alimentarius (2001)).

\section{MATERIALS AND METHODS}

In this study, 27 sunflower honey samples were obtained mainly from Northwest, North and West Bulgaria. The honey samples (about $500 \mathrm{~g}$ ) were kept in glass containers at room temperature. The study used representative samples of bee honey harvested in beekeeping seasons 2017 and 2018. The analyses were performed within one month from the date of receiving the samples at the laboratory. The pollen analysis was carried out by Bulgarian State Standard for Bee Honey 3050-80 and Bulgarian State Standard 2673-80. According to Bulgarian State Standard for Bee Honey 2673-80 honey samples with more than $40 \% \mathrm{H}$. annuus pollen is sunflower honey. The pollen analysis and physicochemical analyzes were done at the Central Laboratory of Veterinary Control and Ecology, Sofia, Bulgaria.

The physicochemical parameters water content, diastase, reducing sugars and sucrose, hydroxymethylfurfural, total acidity and electrical conductivity, proline content and specific rotation were determined according to the European Honey Commission recommended methods (Bogdanov et al. 1997):

-Water content is determined by the refractometric method (Abbe refractometer);

-Determination of diastase activity is after Schade method;

-For reducing sugars and sucrose is used Fehling's reagent;

-Hydroxymethylfurfural was determined after White (in $\mathrm{mg} / \mathrm{kg}$ );

-Total acidity (meq/ $\mathrm{kg}$ ) by titration with $0.1 \mathrm{~N}$ sodium hydroxide with phenolphthalein indicator;

-Electrical conductivity was measured in $20 \%$ weight volume in water (the results are expressed in $\mathrm{mS} / \mathrm{cm}$ );

-Proline content was determined spectrophotometrically. Proline stock solution with $0.8 \mathrm{mg} / \mathrm{mL}$ concentration was prepared.

Statistical analysis of the results was performed using SPSS 20.0 for Windows. Correlations between results were made using the Pearson's correlation coefficient $(r),(p<0.05)$. All results are presented as minimal and maximal value, means \pm standard deviation.

\section{RESULTS}

Melissoplaynological analysis is based on the identification of pollen by microscopic examination, and it needs highly specialized personnel. Another limitation of the method is that sometimes the pollen grains have similar morphologies and it is difficult to be recognized (Bogdanov et al. 2004). In many cases the melissoplaynological analysis presents the dominant pollen type in the honey. In general, all honey samples could be considered as sunflower honey according to their pollen content (up to $41 \%$ $H$. annuus pollen). According to Bulgarian State Standard for Bee Honey 2673-80 honey samples with up to $40 \%$ pollen samples from $H$. annuus can be classified as sunflower honey. The main species are presented in Table 1 . The $H$. annuus pollen varies in the ranges $41-80 \%$. 


\section{ARAŞTIRMA MAKALESI / RESEARCH ARTICLE}

Table 1. Pollen analysis of studied honey samples $(n=27)$

\begin{tabular}{|c|c|}
\hline $\begin{array}{l}\text { Honey } \\
\text { samples }\end{array}$ & $\begin{array}{l}\text { Main species or family, } \\
\% \pm S D\end{array}$ \\
\hline 1 & Asteraceae $80.1 \pm 4.2$ from them Helianthus annuus $-72.1 \pm 3.4$ \\
\hline 2 & Asteraceae $40.4 \pm 2.1$ from them Helianthus annuus $-43.3 \pm 1.7$ \\
\hline 3 & Asteraceae $84.5 \pm 4.4$ from them Helianthus annuus $-71.8 \pm 4.3$ \\
\hline 4 & Asteraceae $52.8 \pm 1.2$ from them Helianthus annuus $-41.7 \pm 0.5$ \\
\hline 5 & Asteraceae $63.8 \pm 3.3$ from them-Helianthus annuus $-60.7 \pm 3.2$ \\
\hline 6 & Asteraceae $70.3 \pm 3.7$ from them-Helianthus annuus $-69.0 \pm 3.6$ \\
\hline 7 & Asteraceae $52.9 \pm 2.8$ from them Helianthus annuus $-48.7 \pm 2.5$ \\
\hline 8 & Asteraceae $57.1 \pm 3.0$ from them Helianthus annuus $-49.3 \pm 2.6$ \\
\hline 9 & Asteraceae $74.9 \pm 3.9$ from them Helianthus annuus $-73.9 \pm 3.8$ \\
\hline 10 & Asteraceae $49.5 \pm 2.6$ from them Helianthus annuus $-48.4 \pm 2.5$ \\
\hline 11 & 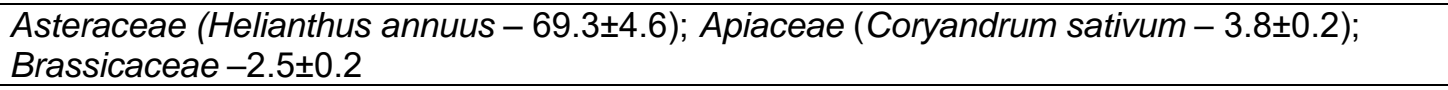 \\
\hline 12 & 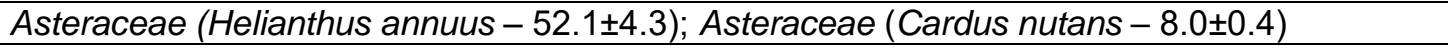 \\
\hline 13 & 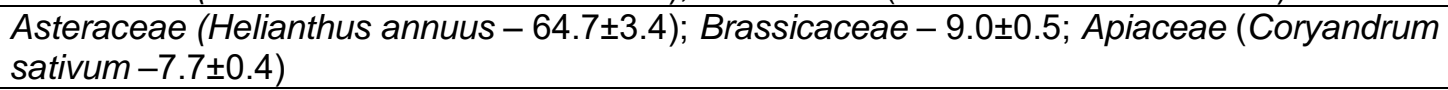 \\
\hline 14 & 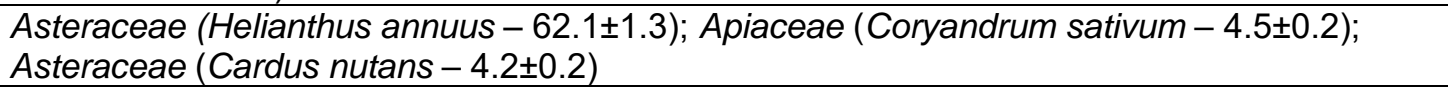 \\
\hline 15 & 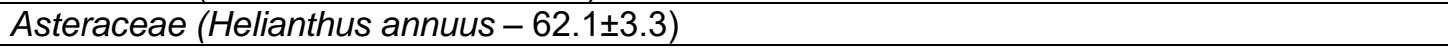 \\
\hline 16 & Asteraceae (Helianthus annuus - 49.5 \pm 2.5$)$ \\
\hline 17 & 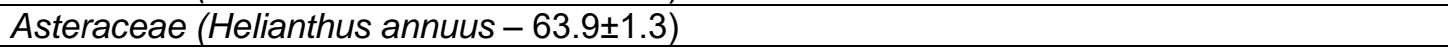 \\
\hline 18 & Asteraceae (Helianthus annuus - 50.0 \pm 2.5$)$ \\
\hline 19 & 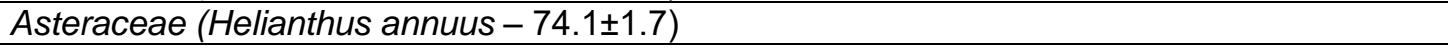 \\
\hline 20 & Asteraceae (Helianthus annuus - 52.5 \pm 1.8 ) \\
\hline 21 & Asteraceae (Helianthus annuus - 57.1 \pm 2.3 ) \\
\hline 22 & Asteraceae (Helianthus annuus $-70.2 \pm 4.1$ ) \\
\hline 23 & Asteraceae (Helianthus annuus - 66.2 \pm 2.0 ) \\
\hline 24 & Asteraceae (Helianthus annuus - 71.5 \pm 3.6 ) \\
\hline 25 & Asteraceae (Helianthus annuus - 55.4 \pm 1.7 ) \\
\hline 26 & Asteraceae (Helianthus annuus - 57.9 \pm 2.0 ) \\
\hline 27 & Asteraceae (Helianthus annuus $-72.7 \pm 1.4$ ) \\
\hline
\end{tabular}

Table 2 presents the results of the analysis of the honey samples: the average values and standard deviation of the physicochemical parameters (water content, reducing sugars, sucrose, diastase, HMF, total acidity, electrical conductivity).

Table 2. Physicochemical parameters of sunflower honey, $n=27$

\begin{tabular}{llll}
\hline \hline Parameters & Min & Max & Mean $\pm S D$ \\
\hline Water content, \% & 15.60 & 19.30 & $17.76 \pm 0.96$ \\
Reducing sugars, \% & 72.50 & 80.80 & $76.15 \pm 2.60$ \\
Sucrose, \% & 0.50 & 3.70 & $1.72 \pm 1.01$ \\
Diastase, Gothe units & 9.00 & 20.80 & $14.50 \pm 3.94$ \\
Hydroxymethylfurfural (HMF), mg/kg & 0.69 & 12.40 & $2.82 \pm 2.65$ \\
Total acidity, meq/kg & 17.70 & 36.00 & $23.73 \pm 7.23$ \\
Electrical conductivity, mS/cm & 0.23 & 0.48 & $0.32 \pm 0.07$ \\
\hline
\end{tabular}




\section{ARAŞTIRMA MAKALESİ / RESEARCH ARTICLE}

Taking into consideration that the honey water content has to be lower than $20 \%$ in general (Council Directive 2001/110 relating to honey, 2002 and Codex Alimentarius, 2001), the values obtained in this study were satisfactory. They ranged from 15.60 to $19.30 \%$.

The main reducing sugars in honey are glucose and fructose. The results for reducing sugars were considered to be sufficient for identification of honey quality. The mean value and standard deviation for the reducing sugars and sucrose are determined as $76.15 \pm 2.60 \%$ and $1.72 \pm 1.01 \%$, respectively. The results for the minimal and maximal values are presented in Table 2.

According to international regulation (Council Directive 2001/110 relating to honey (2002)) diastase activity must not be less than 8 Gothe units. All results are up to this value. In the present study the diastase activity varied by a large range (Table 2).

Hydroxymethylfurfural (HMF) was determined as $2.82 \mathrm{mg} / \mathrm{kg}$ on average. The highest value is under $13 \mathrm{mg} / \mathrm{kg}$.

The mean total acidity value was below 50 meq $/ \mathrm{kg}$ of honey and satisfied the European regulation for this parameter (Council Directive 2001/110 relating to honey (2002). The total acidity ranged from 17.70 to $36.00 \mathrm{meq} / \mathrm{kg}$.

As expected, sunflower honey had the lower values of electrical conductivity (average $0.32 \mathrm{mS} / \mathrm{cm}$ ). Significant moderate correlation between electrical conductivity and specific rotation was found $(r=0.582, p<0.05)$.

The measured proline content of sunflower honey is shown on Figure 1. In the present study the proline content varies in very large ranges $218.50-679.50$ $\mathrm{mg} / \mathrm{kg}$. The average values and standard deviation are $404.94 \pm 144.78 \mathrm{mg} / \mathrm{kg}$. As can be seen from Figure 1 most of the samples have proline values up to $350 \mathrm{mg} / \mathrm{kg}$.

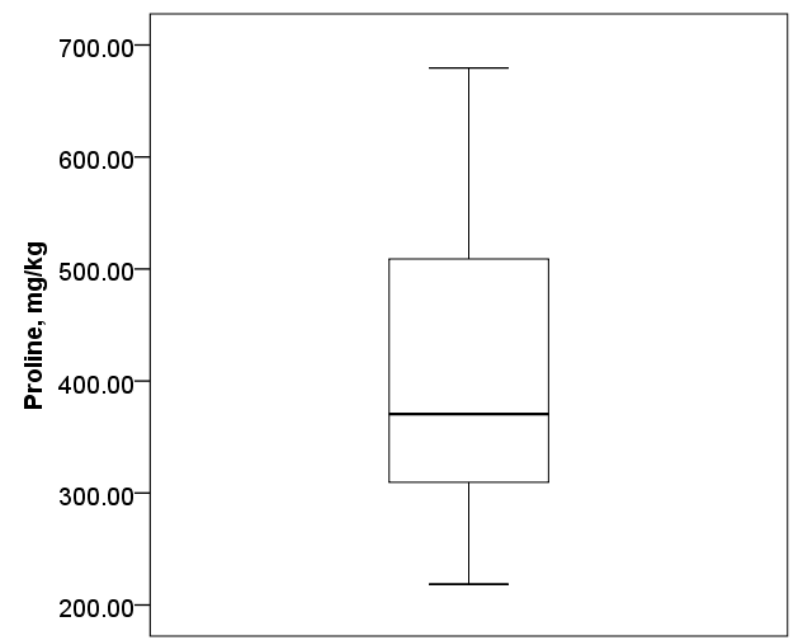

Figure 1. Box plot diagram of proline content in sunflower honey samples. Minimal, maximal and median values are presented.

Specific rotation of sunflower honey samples ranged from -20.20 to $-12.30[\alpha]_{D}{ }^{20}$ and mean value \pm standard deviation $\left(-17.23 \pm 2.43[\alpha]_{D}^{20}\right)$. Sample 14 (value 22.20) is an outlier. The results are shown on Figure 2.

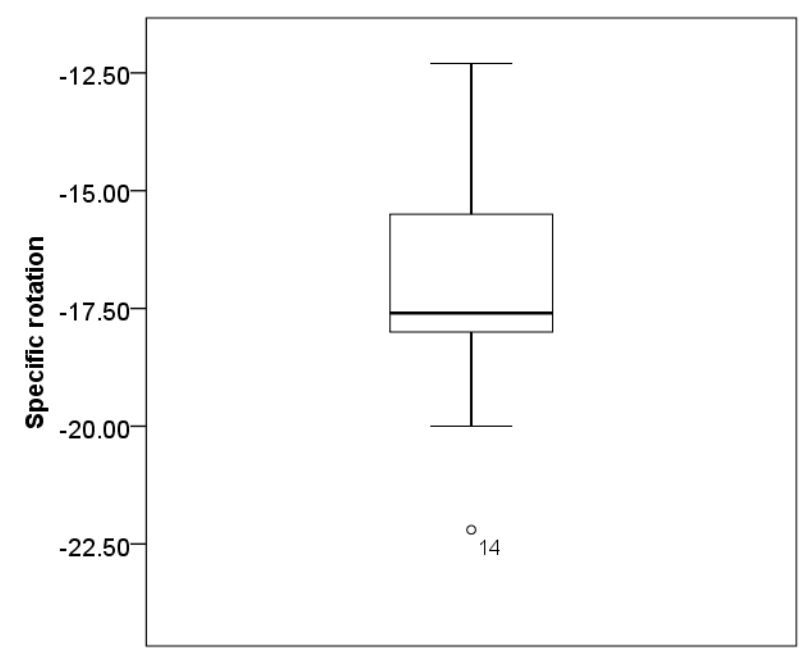

Figure 2. Box plot diagram of specific rotation on sunflower honey samples. Minimal, maximal and median values are presented

\section{DISCUSSION}

Melissopalinological analysis is very important tool in the analysis of honey. Pollen analysis is generally used to determine and confirm the botanical origin of the honey samples. The $H$. annuus pollen was 


\section{ARAŞTIRMA MAKALESI / RESEARCH ARTICLE}

predominant in all honey samples, accounting for more than $40 \%$ pollen grains. Oroian and Ropciuc (2017) reported that their samples had around 60\% of $H$. annuus pollen. In a recent study, Pauliuc and Oroian (2020) presented more than $45 \%$ pollen grains of $H$. annuus (ranges $50-92 \%$ pollen grains).

Water is quantitatively one of the most important components of honey. This parameter describes honey quality. Honeys with high levels of water (more than $20 \%$ in general) tend to ferment more easily. Its content can affect the storage of honey. Furthermore, the water content in honey depends on beekeeping practices and environmental conditions. Also, it can vary from year to year. The average value $(17.76 \pm 0.96 \%)$ is in accordance with the results of Isopescu et al. (2014) for sunflower honey samples.

The sugar content mainly depends on nectar of the flowers used by the bees. Therefore, it varies in the different honey type. In this respect, the content of some sugars and the ratios between them are used to determine honey authenticity (Borrás et al. 2014). Some geographical and climatic conditions can also affect sugar composition of honey (Mărghitaș et al. 2009, Kaskonienè et al. 2010). Reducing sugars are the most abundant sugars in floral honey samples. The sucrose content is under the limits presented by Council Directive 2001/110 relating to honey (2002) and Codex Alimentarius (2001). GropoşilăConstantinescu et al. (2020) presented 74.8\% reducing sugars for commercial sunflower honey samples. This result is very similar to the average value in the present study. Sahinler et al. (2009) reported higher values for sucrose content in sunflower honey $(6.46 \pm 0.78 \%)$ which is higher than the maximal value for the Bulgarian sunflower honey samples (3.70\%).

Enzyme diastase is derived from the glandular secretions of the honey bees. Diastase activity is one of the most important quality parameter. Very often it is used to determine if honey has been heated during storage. Diastase activity loss occurs as temperature increases. The average diastase activity in this study is comparable to those presented by Gropoşilă-Constantinescu et al. (2020) for sunflower honey (about 12 Gothe units). JuanBorrás et al. (2014) evaluated the influence of the country origin on some physicochemical parameters including diastase activity. Their results for diastase activity in sunflower honey samples from Spain, Romania and Czech Republic are very similar to the results in the present study. The diastase activity varies not only according to its botanical origin and country origin but also due to high temperature and storage. Eremia et al. (2019) reported large ranges for diastase activity (15.02 - 30.69 Gothe units).

Hydroxymethylfurfural (HMF) can be found in low concentrations in honey. It is produced from fructose in the presence of free acids. The production of HMF depends on the temperature (Da Silva et al. 2016). Thermal treatment of honey can generate toxic HMF, thereby resulting in quality reduction. For the sunflower honey is typical quick crystallization (Persano Oddo and Piro 2004). This is due to high glucose content in this honey type. Glucose may crystallize at room temperature. For this reason, sometimes the sunflower honey is liquefied at high temperature. This over heating produces HMF. Based on the Codex Alimentarius (2001) and Council Directive 2001/110 relating to honey (2002), HMF level should not exceed $40 \mathrm{mg} / \mathrm{kg}$. The obtained results for HMF are close to those previously reported by Sakača et al. (2019) and Pauliuc and Oroian (2020). The average HMF value and standard deviation (1.19 \pm 1.12 Gothe units) reported by Sakača et al. (2019) are consistent with our results. Juan-Borrás et al. (2015) found higher HMF values $(37.4 \mathrm{mg} / \mathrm{kg}, \quad 37.9 \mathrm{mg} / \mathrm{kg}$, and $39.8 \mathrm{mg} / \mathrm{kg}$ ) in sunflower honey. The authors noted that these values are unacceptable for raw honey. These outlying values are not frequent.

Acidity of honey depends on the presence of organic acids and inorganic ions. Acid measurement in honey evaluates honey fermentation (Belay et al. 2013). Lower value of acid indicates absence of fermentations. The average value of total acidity is comparable to this presented by Kivrak et al. (2017) for sunflower honey.

Values for electrical conductivity higher than 0.80 $\mathrm{mS} / \mathrm{cm}$ are not typical for nectar honeys according to Codex Alimentarius (2001). The obtained minimal and maximal values are in agreement with the result presented by Persano Oddo and Piro (2004). The correlation between electrical conductivity and specific rotation was also supported by Belay et al. (2013) and Pridal and Vorlova (2002).

In the present study most of the samples have proline values up to $350 \mathrm{mg} / \mathrm{kg}$. These results are confirmed by Wen et al. (2017). They received very similar data. For example, the range of proline content in sunflower honeys is from 214.06 to 601.11 $\mathrm{mg} / \mathrm{kg}$. Czipa et al. (2012) found higher values for 


\section{ARAŞTIRMA MAKALESI / RESEARCH ARTICLE}

proline in sunflower honey. Large proline variation for sunflower honeys is typical. Although proline content has been considered as a useful parameter of honey quality, other parameters can also be used for honey quality identification. International regulations of honey quality do not present information for the proline content in honey. The proline content varied in the different honey types (Cotte et al. 2004, Keckes et al. 2013, Wen et al. 2017).

Specific optical rotation is a parameter which may distinguish blossom honeys (negative values) and honeydew honeys (positive values), (Persano Oddo and Piro 2004). The concentration of various sugars are responsible for specific rotation of honey. The results obtained indicate that honey samples were from blossom honey, rotating negative (laevorotatory). Significant moderate correlation between electrical conductivity and specific rotation was found $(r=0.582, p<0.05)$.

\section{Conclusion}

All honey samples have more than $40 \% \mathrm{H}$. annuus pollen and can be classified as sunflower honey. The parameters water content, reducing sugars, sucrose, diastase, HMF, total acidity, electrical conductivity, proline and specific rotation of sunflower honey satisfied the quality parameters established by international regulations. This study provides useful information for characterization of sunflower honey from Bulgaria.

Source of Finance: Not applicable.

Conflict of Interest: The authors declare that there is no conflict of interest regarding the publication of this article.

Author contribution: Vanya Manolova, Ivayla Parvina, Todorka Yankovska - Stefanova, Ralitsa Balkanska collected the honey samples. Vanya Manolova and Ralitsa Balkanska designed the study and carried out the experiments. Ralitsa Balkanska wrote the manuscript.

Ethical issue: Not applicable.

Acknowledgment: We would like to thank the anonymous reviewers who provided valuable comments to the final version of the manuscript.

\section{REFERENCES}

Ahmed, M., Shafiq, Ml., Khaleeq, A., Huma, R., Qadir, MA., Khalid, A., Ali A., Samad, A. 2016. Physiochemical, biochemical, minerals content analysis, and antioxidant potential of national and international honeys in Pakistan. Journal of Chemistry 2016: 1-10. doi: 10.1155/2016/8072305.

Aleksiev, G. 2019. Honey trade in Bulgaria and its impact on the apicultural sector. Trakia Journal of Sciences, 17(1): 451-454. doi:10.15547/tjs.2019.s.01.073.

Atanassova, J., Yurukova, L., Lazarova, M. 2012. Pollen and inorganic characteristics of Bulgarian unifloral honeys. Czech Journal of Food Sciences, 30(6): 520-526. doi: 10.17221/44/2012-CJFS.

Belay, A., Solomon, WK., Bultossa, G., Adgaba, N., Melaku, S. 2013. Physicochemical properties of the Harenna forest honey, Bale, Ethiopia. Food Chemistry, 141(4): 3386-3392.

doi: 10.1016/j.foodchem.2013.06.035.

Bilandžić, N., Tlak Gajger, I., Kosanović, M., Čalopek, B., Sedak, M., Solomun Kolanović, B., Varenina, I., Luburić, ĐB., Varga, I., Đokić, M. 2017. Essential and toxic element concentrations in monofloral honeys from southern Croatia. Food Chemistry, 234: 245-253.

doi: 10.1016/j.foodchem.2017.04.180.

Bogdanov S., Martin P., Lüllmann C. 1997. Harmonized methods of the European Honey Commission, Apidologie extra issue, 1-59.

Bogdanov, S., Ruoff, K., Persano Oddo, L. 2004. Physicochemical methods for the characterisation of unifloral honeys: a review. Apidologie, 35(1), S4-S17. doi.org/10.1051/apido:2004047.

Borrás, M., Domenech, E., Hellebrandova, M., Escriche, E. 2014. Effect of country origin on physicochemical, sugar and volatile composition of acacia, sunflower and tilia honeys. Food Research International, 60: 86-94. doi: 10.1016/j.foodres.2013.11.045.

Bulgarian State Standard (1980). Bee Honey 267380. 


\section{ARAŞTIRMA MAKALESI / RESEARCH ARTICLE}

Bulgarian State Standard for Bee Honey 3050-80. Rules for sampling and tasting methods. Qualitative indicators on honey.

Codex Alimentarius Commission, "Revised Codex Standard for Honey Codex Stan 12-1981, Rev. 1 (1987), Rev. 2 (2001) Amended in 2019., pp. 1-8.

Cotte, JF., Casabianca, H., Giroud, B., Albert, M., Lheritier, J., Grenier-Loustalot, MF. 2004. Characterization of honey amino acid profiles using high-pressure liquid chromatography to control authenticity. Analytical and Bioanalytical Chemistry, 378(5): 1342-1350. doi: 10.1007/s00216003-2430-z.

Council Directive 2001/110 relating to honey (2002). Official Journal of the European Communities, L10, 47-52.

Czipa, N., Borbély, M., Gyori, Z. 2012. Proline content of different honey types. Acta Alimentaria, 41(1): 26-32. doi: 10.1556/AAlim.2011.0002.

Da Silva, PM., Gauche, C., Gonzaga, LV., Costa, ACO., Fett, R. 2016. Honey: Chemical composition, stability and authenticity. Food Chemistry, 196: 309-323. doi: 10.1016/j.foodchem.2015.09.051.

De-Melo, AAM., de Almeida-Muradian, LB., Sancho, MT., Pascual-Mate, A. 2018. Composition and properties of Apis mellifera honey: A review. Journal of Apicultural Research, 57(1): 5-37. doi: 10.1080/00218839.2017.1338444.

Dinkov, D. 2014. Quality parameters of Bulgarian kinds of bee honey. Macedonian Veterinary Review, 37(1): 35-41. doi: 10.14432/j.macvetrev.2014.01.007.

Eremia, N., Neicovcena, I., Griţunic, I. 2019. Physical and chemical indicators, content of micro and macroelements and heavy metals in sunflower honey. Scientific PapersAnimal Science Series: Lucrări Ştiinţifice Seria Zootehnie, 71: 105-108.

Gropoşilă-Constantinescu, D., Popa, G., Vişan, V., Mărgărit, GL., Toma, R., Barba, D. 2020. Comparative study of the quality of traditional honey and industrial honey. Scientific Bulletin. Series $F$.
Biotechnologies, 24(1): 50-54.

Isopescu, RD., Josceanu, AM., Minca, I., Colta, T., Postelnicescu, P., Mateescu, C. 2014. Characterization of Romanian honey based on physico-chemical properties and multivariate analysis. Revista de Chimie (Bucharest), 65(4), 381-385.

Juan-Borrás, M., Domenech, E., Conchado, A., Escriche, I. 2015. Physicochemical quality parameters at the reception of the honey packaging process: Influence of type of honey, year of harvest, and beekeeper. Journal of Chemistry, Article ID 929658, 16. doi:10.1155/2015/929658

Juan-Borrás, M., Domenech, E., Hellebrandova, M., Escriche, I. 2014. Effect of country origin on physicochemical, sugar and volatile composition of acacia, sunflower and tilia honeys. Food Research International, 60: 86-94. doi: 10.1016/j.foodres.2013.11.045.

Kaskonienè, V., Venskutonis, PR., Ceksterytè, V. 2010. Carbohydrate composition and electrical conductivity of different origin honeys from Lithuania. LWT-Food Science and Technology, 43(5): 801-807. doi: 10.1016/j.Iwt.2010.01.007.

Keckes, J., Trifkovic, J., Andric, F., Jovetic, M., Tesi, Z., Milojkovic-Opsenica, D. 2013. Amino acids profile of serbian unifloral honeys. Journal of the Science of Food and Agriculture, 93: 3368-3376. doi: 10.1002/jsfa.6187.

Kivrak, S., Kivrak, I., Karababa, E. 2017. Characterization of Turkish honeys regarding of physicochemical properties, and their adulteration analysis. Food Science and Technology Campinas, 37(1): 80-89. doi: 10.1590/1678-457X.07916.

Mărghitaș, LA., Dezmirean, D., Moise, A., Bobis, O., Laslo, L., Bogdanov, S. 2009. Physicochemical and bioactive properties of different floral origin honeys from Romania. Food Chemistry, 112(4): 863-867. doi: 10.1016/j.foodchem.2008.06.055.

Nikolova, Kr., Eftimov, T., Aladjadjiyan, A. 2014. Fluorescence spectroscopy as method for quality control of honey. Advances in Research, 2(2): 95-108. 


\section{ARAŞTIRMA MAKALESI / RESEARCH ARTICLE}

Oroian, M., Ropciuc, S. 2017. Honey authentication based on physicochemical parameters and phenolic compounds. Computers and Electronics in Agriculture, 138: 148-156. doi: 10.1016/j.compag.2017.04.020.

Pauliuc, D., Oroian, M. 2020. Organic acids and physico-chemical parameters of Romanian sunflower honey. Food Environment Safety, 19(2): 148-155.

Persano Oddo, L., Piro, R. 2004. Main European unifloral honeys: descriptive sheets. Apidologie, 35(1): 38-81. doi: 10.1051/apido:2004049.

Přidal, A., Vorlová, L. 2002. Honey and its physical parameters. Czech Journal of Animal Science, 47(10): 439-444.

Sahinler, N., Gül, A., Akyol, E., Öksüz, A. 2009. Heavy metals, trace elements and biochemical composition of different honey produce in Turkey. Asian Journal of Chemistry, 21(3), 1887-1896.

Sakača, MB., Jovanova, PT., Marića, AZ., Pezob LL., Kevrešana, ŽS., Novakovića, AR., Nedeljkovića, NM. 2019. Physicochemical properties and mineral content of honey samples from Vojvodina (Republic of Serbia). Food Chemistry, 276: 15-21. doi: 10.1016/j.foodchem.2018.09.149.
Saxena, S., Gautam, S., Sharma, A. 2010. Physical, biochemical and antioxidant properties of some Indian honeys. Food Chemistry, 118(2): 391-397. doi: 10.1016/j.foodchem.2009.05.001.

Silva, LR., Videira, R., Monteiro, AP., Valentão, P., Andrade, PB. 2009. Honey from Luso region (Portugal): Physicochemical characteristics and mineral contents. Microchemical Journal, 93(1): 73-77. doi: 10.1016/j.microc.2009.05.005.

Valdés-Silverio, LA., Iturralde, G., García-Tenesaca, M., Paredes-Moreta, J., Narváez-Narváez, DA., Rojas-Carrillo, M., Tejera, E., BeltránAyala, P., Giampieri, F., Alvarez-Suarez, JM. 2018. Physicochemical parameters, chemical composition, antioxidant capacity, microbial contamination and antimicrobial activity of Eucalyptus honey from the Andean region of Ecuador. Journal of Apicultural Research, 57(3): 382-394. doi: 10.1080/00218839.2018.1426349.

Wen, Y., Zhang, J., Li, Y., Chen, L., Zhao, W., Zhou, J., Jin, Y. 2017. Characterization of Chinese unifloral honeys based on proline and phenolic content as markers of botanical origin, using multivariate analysis. Molecules, 22(5): 1-13. doi: $10.3390 /$ molecules22050735. 